\title{
Mercury in terrestrial forested systems with highly elevated mercury deposition in southwestern China: The risk to insects and potential release from wildfires
}

\author{
Jun Zhou ${ }^{\text {a, b }}$, Zhangwei Wang ${ }^{\text {a, }}{ }^{*}$, Ting Sun ${ }^{\text {a, b }}$, Huan Zhang ${ }^{\text {a, b }}$, Xiaoshan Zhang ${ }^{a}$ \\ ${ }^{a}$ Research Center for Eco-Environmental Sciences, Chinese Academy of Sciences, Beijing 100085, China \\ ${ }^{\mathrm{b}}$ University of Chinese Academy of Sciences, Beijing 100049, China
}

\section{A R T I C L E I N F O}

\section{Article history:}

Received 15 October 2015

Received in revised form

28 December 2015

Accepted 1 January 2016

Available online 1 February 2016

\section{Keywords:}

Subtropical forest

Total gaseous mercury

Mercury pool

Vegetation tissues

\begin{abstract}
A B S T R A C T
Forests are considered a pool of mercury in the global mercury cycle. However, few studies have investigated the distribution of mercury in the forested systems in China. Tieshanping forest catchment in southwest China was impacted by mercury emissions from industrial activities and coal combustions. Our work studied mercury content in atmosphere, soil, vegetation and insect with a view to estimating the potential for mercury release during forest fires. Results of the present study showed that total gaseous mercury (TGM) was highly elevated and the annual mean concentration was $3.51 \pm 1.39 \mathrm{ng} \mathrm{m}^{-2}$. Of the vegetation tissues, the mercury concentration follows the order of leaf/ needle $>$ root $>$ bark $>$ branch $>$ bole wood for each species. Total ecosystem mercury pool was $103.5 \mathrm{mg} \mathrm{m}^{-2}$ and about $99.4 \%$ of the mercury resides in soil layers $(0-40 \mathrm{~cm})$. The remaining $0.6 \%$ $\left(0.50 \mathrm{mg} \mathrm{m}^{-2}\right)$ of mercury was stored in biomass. The large mercury stocks in the forest ecosystem pose a serious threat for large pluses to the atmospheric mercury during potential wildfires and additional ecological stress to forest insect: dung beetles, cicada and longicorn, with mercury concentration of $1983 \pm 446,49 \pm 38$ and $7 \pm 5 \mathrm{ng} \mathrm{g}^{-1}$, respectively. Hence, the results obtained in the present study has implications for global estimates of mercury storage in forests, risks to forest insect and potential release to the atmosphere during wildfires.
\end{abstract}

() 2016 Elsevier Ltd. All rights reserved.

\section{Introduction}

Mercury is a significant global contaminant due to its biogeochemical properties and its toxicity that can affect the health of people and ecosystems (US EPA, 1997). Anthropogenic activities related to industrialism disperse mercury, mainly inorganic mercury, which can be transformed by bacteria to methylmercury and biomagnified through aquatic and terrestrial food webs resulting in human health concerns through fish and rice consumption (Clarkson, 1998; Zhou et al., 2015a). Unlike other heavy metals, the biogeochemical cycling of mercury between atmosphere and forest terrestrial ecosystem is particularly important for subtropical ecosystems because huge amount of biomass was contained in subtropical forests and peat lands and forest was supposed to a large sinks of atmospheric mercury (Zhou et al., 2013, 2015b; Stankwitz

\footnotetext{
* Corresponding author.

E-mail address: wangzhw@rcees.ac.cn (Z. Wang).
}

et al., 2012). Coupled with global warming accelerated in northern latitudes (Raisanen, 1997) and high drought frequency in southwest China (Zhang and Zhou, 2015), these were of great scientific and public interest because of heightening wildfire activity and increasing mercury and carbon release to the atmosphere (Melendez-Perez et al., 2014; Friedli et al., 2007).

Vegetation is known to exert significant influence on the atmospheric mercury deposition and soil mercury evasion in the terrestrial ecosystem (Wang et al., 2009; Choi and Holsen, 2009; Mazur et al., 2014). Total gaseous mercury (TGM) in the atmosphere makes it likely that the dry deposition flux via stomatal uptake constitutes a large component of total dry deposition (Zhou et al., 2013). Upon deposition to the ground in throughfall or contained in biomass material (senesced leaves, needles, bark, twigs and dead wood), mercury is sequestered by reduced sulfur groups in the organic soil (Grigal, 2003; Obrist et al., 2009), re-emitted back to the atmosphere (Choi and Holsen, 2009; Mazur et al., 2014) and leached into runoff or soil solution (Wang et al., 2009; Grigal et al., 2000). Atmospheric mercury deposition and soil 
mercury pool in terrestrial ecosystems have been extensively studied over the past decade (Grigal et al., 2000; Grigal, 2003; Obrist et al., 2009), yet little work has been done to assess mercury concentrations in organisms occupying forest ecosystems. Insects are the important constituent of the ecosystem and provide a significant source of food for wildlife such as spider, birds and some other small mammals. It is reported that some insects accumulate large amount of mercury in their bodies and result in physiological toxicity (Wyman et al., 2011; Townsend et al., 2014). Additionally, mercury would be transported to organisms on the higher position from insects along food chains (Zhang et al., 2010).

As an economic giant of the world, China has experienced dramatic economic growth over the past three decades, which was proved to be the world's largest energy consumer and anthropogenic mercury emission. According to recent studies at subtropical forest in China, the biome has high concentrations of mercury in litter (Fu et al., 2010; Zhou et al., 2013). Some animals in forest ecosystems may be uniquely adapted to this environment (Holmes and Sawyer, 1975; Townsend et al., 2014) and may be highly vulnerable to increased mercury loads. However, few assessments exist to determine if biota in forest systems is bioaccumulated and impacted by atmospherically deposited mercury. Furthermore, in recent years, sections of forests in China suffer from massive wildfires, consuming on average up to millions of hectares each year and the annual average mercury emission from forest fires was 0.78 t during 2000-2010 (Chen et al., 2013).

In the current study, we investigated the mercury concentrations in air, soil, plant and insect of the TFP forest in southwestern China. However, this is the first study, to the best of our knowledge, to explore mercury bioaccumulation in insects and to assess the mercury distribution and pool in biomass as well as potential risk of mercury emission caused by fires in forest of China. The primary objective of this paper is (1) to quantify the mercury distribution in air, soil, vegetation, insect and mercury stocks in the forest ecosystem, and (2) to estimate the potential risk to insects and mercury release during future wildfires.

\section{Materials and methods}

\subsection{Study area}

A field experiment was carried out in a Masson pine (Pinus massoniana Lamb.) stand planted in 1962 following the clear cutting of a natural Masson pine forest at Tieshanping Forest Park $\left(106^{\circ} 41.24^{\prime} \mathrm{E}, 29^{\circ} 37.42^{\prime}\right)$, which is located about $20 \mathrm{~km}$ northeast of the center of Chongqing City, at an elevation from 200 to $550 \mathrm{~m}$ (Fig. 1). TFP is one of the Sino-Norwegian multidisciplinary Integrated Monitoring Program on Acidification of Chinese Terrestrial Systems (IMPACTS) project monitoring sites. The climate is mainly controlled by the southwest monsoon with a mean annual precipitation of $1028 \mathrm{~mm}$ and $75 \%$ of the rainfall occurs during wet seasons (May-October). Annual mean air temperature in the study area is $18.2{ }^{\circ} \mathrm{C}$. Due to warm and wet summer, soil organic matter turnover rates are high (Raich and Schlesinger, 1992; Zhu et al., 2013). The stand is homogeneous, dominated by Masson pine and some associated species such as Cunninghamia lanceolata (Lamb.) Hook. and Schima superba Gardn. et Champ. Clay mineralogy is dominated by kaolinite and the soil is typically mountain yellow earth (corresponding to a Haplic Acrisol in FAO; Surhone et al., 2010) and its texture is haplic acrisol/alisol.

Chongqing is an important industrial region in southwest China, and consumes large amount of coal. Consequently, annual mercury emissions just from coal-fired was 4.97 t (Wang et al., 2006) and mercury pollution was regarded as major environmental burdens in Chongqing (Yang et al., 2009). Via atmospheric long-distance transport, large amounts of mercury deposited to the surrounding region of the city. Based on our previous studies here, the annual total input fluxes of mercury were $291.2 \mu \mathrm{g} \mathrm{m}^{-2} \mathrm{yr}^{-1}$ (Wang et al., 2009), which was several or even dozens of times higher than those in North America and Europe (Zhou et al., 2016). About over two-thirds of the deposited mercury was resident in the forest, which resulted in elevated mercury concentration in organic horizons $\left(191 \pm 65 \mathrm{ng} \mathrm{g}^{-1}\right)$ and mercury pool $\left(8.2 \pm 2.6 \mathrm{mg} \mathrm{m}^{-2}\right)$, (Zhou et al., 2015b), and thus it can be deduced that the subtropical forest was a great sink of atmospheric mercury.

\subsection{TGM in atmosphere}

The collection and measurement of TGM samples as well as the quality control procedure have been described in details in our previous study (Zhou et al., 2015b). Briefly, TGM was continuous monitoring in four seasons from March 2014 to January 2015 over the canopy in the forest with manual pure gold quartz trap. The gold traps were sampled at 8:00 am and 6:00 pm every day, representing daytime and night, respectively. All the gold traps were brought back to TFP Forestry Station for mercury quantification by CVAFS detector (Brooks Rand III, US EPA, 1999) using dual gold trap amalgamation procedure after every sampling.

\subsection{Mercury in soil, vegetation and insect}

In this study, three sample plots of $10 \times 10 \mathrm{~m}^{2}$ were set up in January 2015. A buffer strip of about $100 \mathrm{~m}$ surrounded each of the plots. The plots were all quite flat, with slope less than $10^{\circ}$. Ground organic material and mineral soil samples were collected from $20 \mathrm{~cm} \times 20 \mathrm{~cm}$ squares and transported in polyethylene bags with airtight seals. The organic material included litter (leaves and needles, small twigs), organic soil layers (O horizons) which were collected as horizontal slices and assigned Oi (undecomposed surface litter), Oe (partially decomposed litter), Oa (decomposed organic humus, and coarse woody debris) designations based on the approximate degree of decomposition. Samples in the depth mineral soil profiles were collected from top layer to the depth of $40 \mathrm{~cm}$.

Samples of herb standing vegetation (Dicranopteris pedata, Woodwardia japonica and moss) were collected from the subplots and separated into root, stem and leaf. Samples of shrub were taken from Randia cochinchinensis and Loropetalum chinense including root, stem, branch and leave in each subplot. Samples of overstory collected from Masson pine were needles, bark, cores and roots. Each sample was collected in triplicate in each plot. To calculate the mercury stocks in vegetation, concentrations were assumed to be the same for understory and overstory plant components.

Three insect species which were cicada (Platypleura kaempferi, Chremistica ochracea and Oncotympana maculaticollis), longicorn (Anoplophora chinensis) and dung beetle (Geotrupidae) were collected by hand in June and August, 2014 and sealed in polythene bags. Samples of insects were froze immediately in a refrigerator at $-4{ }^{\circ} \mathrm{C}$ until used.

Soil samples were air-dried in a clean environment and vegetation samples were washed thoroughly with tap water and then with deionized water, dried at $60{ }^{\circ} \mathrm{C}$ for $48 \mathrm{~h}$ to constant weight. The insect samples were washed thoroughly with deionized water and then freezing-dried for $72 \mathrm{~h}$ in the laboratory. Subsequently, plant and insect samples were completely ground to a fine powder in a pre-cleaned food blender, passed through 100 mesh and stored in polyethylene bags to avoid cross-contamination. Practices to avoid mercury contamination included wearing clean polyethylene gloves, using pre-cleaned plastic tools and double-bagging all samples. 


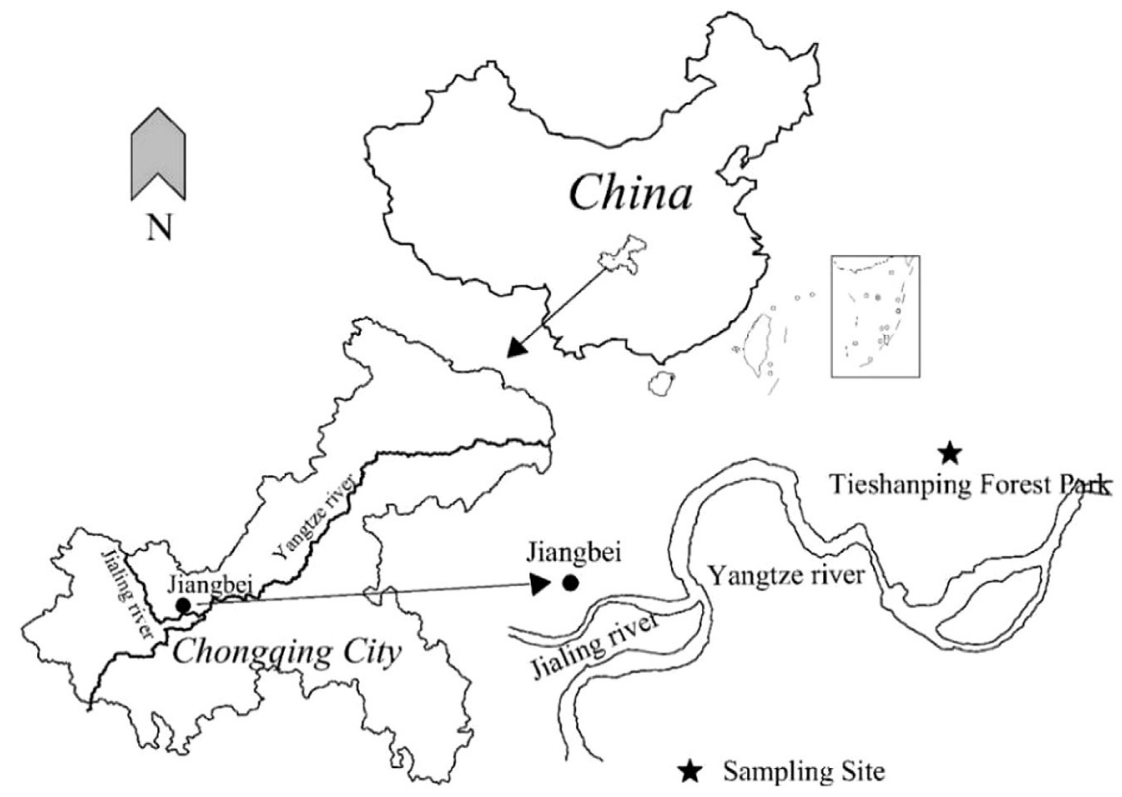

Fig. 1. Location of the study site.

The mercury concentration in plant, soil and insect was measured by using the Direct Mercury Analyzer (DMA-80, Milestone). Each sample was determined in duplicate and analyses were repeated when the coefficient of variability of samples exceeded $5 \%$. The detection limits were $0.34 \mathrm{ng} \mathrm{g}^{-1}$. Percent relative differences (PRD), obtained from five duplicated measurements of samples were from $\pm 3.7 \%$ to $\pm 5.4 \%$. In this study, the Certified Reference Materials of soil (IGGE IRMA China, $590 \pm 80 \mathrm{ng} \mathrm{g}^{-1}$ ), citrus leaf (GBW10020, $150 \pm 20 \mathrm{ng} \mathrm{g}^{-1}$ ) and fish tissue (GBW10029, $850 \pm 30 \mathrm{ng} \mathrm{g}^{-1}$ ) were used for quality control. The recoveries of certified standards ranged from $94 \%$ to $111 \%$.

\subsection{Mercury pools in the ecosystem}

Vegetation mercury storage was calculated by multiplying the average biomass and mercury concentration of the corresponding species. Standing biomass of trees was estimated using diameter at breast height $(\mathrm{DBH})>3 \mathrm{~cm}$, which was measured in our plots. Empirically region specific allometric relationships relating tree DBH and biomass were used, including trunk, branch, needle, bark and root, respectively (Zhang et al., 2006). Above-ground understory biomass including herbs, shrubs and seedlings $(\mathrm{DBH}<3 \mathrm{~cm})$ were measured by complete harvests of three randomly located replicate quadrates $\left(1 \mathrm{~m}^{2}\right.$ each) at each plot in January when annual herb biomass reached its maximum, and forest floor litter and moss was also collected. All these samples were taken to the laboratory and dried at $70{ }^{\circ} \mathrm{C}$ for $48 \mathrm{~h}$ and weighted. Mercury stocks ( $\mathrm{M}_{\mathrm{vege}}$ tation, $\mathrm{mg} \mathrm{m}^{-2}$ ) in vegetation were calculated following formula:

$\mathrm{M}_{\mathrm{vegetation}}=\sum_{v=1}^{n} c_{\mathrm{V}} \times m_{\mathrm{V}}$

Where $c_{v}\left(\mathrm{mg} \mathrm{g}^{-1}\right)$ and $m_{v}\left(\mathrm{~g} \mathrm{~m}^{-2}\right)$ are the mercury concentration and mass of each organ ( $v$ ) of vegetation, respectively.

Mercury stocks $\left(\mathrm{M}_{\mathrm{litter}}, \mathrm{mg} \mathrm{m}^{-2}\right.$ ) in ground litter layer was estimated by multiplying the dry mass $\left(m_{g}, \mathrm{~g} \mathrm{~m}^{-2}\right)$ of litter and the corresponding litter mercury concentration $\left(c_{g}, \mathrm{mg} \mathrm{g}^{-1}\right)$. Litter biomass were measured by complete collection of randomly located replicate quadrates $\left(\mathrm{n}, 1 \mathrm{~m}^{2}\right.$ each) at each plot.
$\mathrm{M}_{\mathrm{litter}}=\sum_{g=1}^{n} c_{\mathrm{g}} \times m_{\mathrm{g}} / n$

Soil mercury concentration $\left(c_{j}, \mathrm{mg} \mathrm{g}^{-1}\right)$ and bulk density $\left(\mathrm{Bd}_{\mathrm{j}}, \mathrm{g}\right.$ $\mathrm{m}^{-3}$ ) of specific layers were used to determine the mercury storage in each soil layer $(\mathrm{j})$. The mercury storage in each soil layer divided the corresponding depth $(\mathrm{m})$ and then added together to estimate the mercury storage $\left(\mathrm{M}_{\text {soil, }} \mathrm{mg} \mathrm{m}^{-2}\right)$ in the depth of $40 \mathrm{~cm}$. Thus, $\mathrm{M}_{\text {soil }}$ was calculated according to the following formula (3):

$\mathrm{M}_{\text {soil }}=\sum_{j=1}^{n} \mathrm{c}_{\mathrm{j}} \times \mathrm{Bd}_{\mathrm{j}} / \mathrm{d}_{\mathrm{j}}$

Then, mercury storage $\left(\mathrm{M}_{\mathrm{Hg}}\right)$ in forest ecosystem was estimated as

$\mathrm{M}_{\mathrm{Hg}}=\mathrm{M}_{\mathrm{vegetation}}+\mathrm{M}_{\text {litter }}+\mathrm{M}_{\text {soil }}$

\section{Results and discussion}

\subsection{Mercury in atmosphere}

TGM concentrations were measured for 132 days in four seasons from March 2014 to January 2015 (Fig. 2). The average TGM concentration in TFP was $3.51 \pm 1.39 \mathrm{ng} \mathrm{m}^{-2}$, which was more than 2 times higher than the background concentration of the Northern Hemisphere (Fu et al., 2015). From comparison of the mean values of TGM or gaseous elemental mercury (GEM) with the results from the monitoring sites in rural or remote areas of China (Fu et al. 2015, 1.60-5.07 $\mathrm{ng} \mathrm{m}^{-2}$ ), the concentration of the TFP site were also higher than those of most sites, which reflects the severe atmospheric mercury pollution problem in our study area. As we stated above, due to coal combustion, cement production, waste incineration, chloro-alkali plants, urban area of Chongqing is regarded as the main contributor of mercury emission to the regional atmosphere (Wang et al., 2006). Additionally, inland China, 


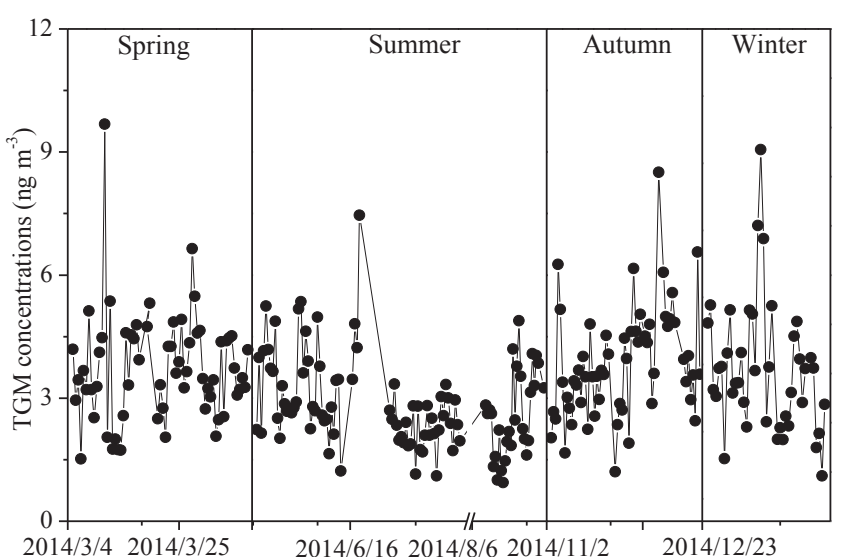

Fig. 2. TGM concentrations at TFP in four seasons from March 2014 to January 2015.

such as Guizhou and Hunan province which has large mercury mine, coal burning (with high mercury content coal), non-ferrous metal smelting activities, were regarded as one of the highest atmospheric mercury source regions (Feng and Qiu, 2008; Li et al., 2009; Ye et al., 2015). The air masses that pass over these mercury sources by southeast monsoon may also result in elevated mercury concentrations.

However, the TGM concentrations of TFP were much lower than that in urban district of Chongqing city which was up to $6.74 \pm 0.37 \mathrm{ng} \mathrm{m}^{-2}$ (Yang et al., 2009). Yang et al. (2009) also found that the GEM did not differ among the transport, industrial and commercial areas, but were obviously lower in the educational/ recreational and natural conservation areas, indicating that industrial and commercial activity emission sources may contribute to atmospheric mercury in urban regions. While mercury emission from coal combustion has been well known to be a major part of anthropologic mercury sources (Wang et al., 2006), the major energy consumption of industrial regions generally located near the core urban areas. Our study area was relatively away from urban zone and no local anthropogenic sources existed and resulted in lower TGM concentrations. Additionally, TGM concentrations in all suburban and remote areas without local emission source in China were significantly lower than that in nearby cities because of anthropologic mercury emission (Fu et al., 2015).

Obvious seasonal variations of TGM concentrations were observed in TFP. The highest seasonal average TGM concentration occurs in winter $\left(4.40 \pm 1.46 \mathrm{ng} \mathrm{m}^{-3}\right)$, while significantly lower concentration was in summer $\left(2.83 \pm 1.12 \mathrm{ng} \mathrm{m}^{-3}, \mathrm{p}<0.05\right)$, and comparable concentrations were found in spring $\left(3.73 \pm 1.31 \mathrm{ng} \mathrm{m}^{-3}\right)$ and autumn $\left(3.84 \pm 1.34 \mathrm{ng} \mathrm{m}^{-3}\right)$. But the TGM concentrations showed no obvious variation at daytime $\left(3.67 \pm 1.47 \mathrm{ng} \mathrm{m}^{-3}\right)$ and night $\left(3.74 \pm 1.33 \mathrm{ng} \mathrm{m}^{-3}\right)$ during the study period. The similar seasonal trends were already observed from other studies in China (Fu et al., 2008, 2010, 2015) and may be related to the emission sources, meteorology and atmospheric oxidant levels (Poissant et al., 2002; Yang et al., 2009). The peculiar meteorological conditions in the summer of Chongqing may contribute to lower GEM. Frequent and plenty of raining in summer (about $42 \%$ of annual amount, Li et al., 2008) may efficiently remove $\mathrm{Hg}^{2+}$ from the air through wet deposition (Zhou et al., 2013). Ozone $\left(\mathrm{O}_{3}\right)$ concentrations averaged $18.3 \pm 15.8 \mu \mathrm{g} \mathrm{m} \mathrm{m}^{-3}$ during the winter months, increasing to $48.4 \pm 32.4 \mu \mathrm{g} \mathrm{m}^{-3}$ during the summer in Chongqing (Xu et al., 2015), while higher contents of oxidants such as $\mathrm{O}_{3}, \mathrm{HO}, \mathrm{HO}_{2}, \mathrm{Cl}_{2}$ and $\mathrm{Br}_{2}$ may result in quick oxidation of $\mathrm{Hg}^{0}$ to $\mathrm{Hg}^{2+}$ (Ariya et al., 2002). In winter, however, higher GEM might be also caused by increased coal combustion for domestic heating, which can be indicated that concentration of sulphur dioxide $\left(\mathrm{SO}_{2}\right)$ in winter was more than two-fold higher than that in summer of Chongqing (Xu et al., 2015).

\subsection{Mercury concentrations and pools in biomass}

\subsubsection{Mercury concentrations in biomass}

Mercury concentrations in plant components were presented in Table 1 . Of the vegetation biomass tissues, the mercury concentration follows the order of leaf/ needle $>$ root $>$ bark $>$ branch $>$ bole wood for each species. The mercury concentrations in the leaves and needles ranged from 78 to $244 \mathrm{ng} \mathrm{g}^{-1}$, and the highest values in the dominant shrub leaf concentrations of $S$. superba and Ilex chinensis (148-210 $\mathrm{ng} \mathrm{g}^{-1}$ ). Mosses were known to accumulate atmospheric mercury efficiently (Rasmussen, 1995) so that the mercury content of $145 \pm 23 \mathrm{ng} \mathrm{g}^{-1}$ observed comparable to forest leaves can be rationalized. Our measured foliar mercury levels were generally much higher than the published concentrations: Grigal (2003) listed a mean mercury concentration of $26 \mathrm{ng} \mathrm{g}^{-1}$ for live foliage; and a series of papers list foliage concentrations of various tree species between 15 and $59 \mathrm{ng} \mathrm{g}^{-1}$ (St. Louis et al., 2001; Grigal et al., 2000; Rasmussen, 1991; Melieres et al., 2003; Gong et al., 2014; Blackwell and Driscoll, 2015). Combining with on our previous study in remote and suburb areas in China (Wang et al., 2009; Zhou et al., 2013, 2015b), it is interesting to find that litter or litterfall mercury concentrations were much higher than that in North America and Europe as presentation above. Numerous previous research, by both laboratory studies and field observations, confirmed that the atmosphere is nearly the exclusive source of mercury in foliage (Barghigiani et al., 1991; Johnson, 1995; St. Louis et al., 2001; Stamenkovic and Gustin, 2009; Niu et al., 2011). Fu et al. (2015) summarized that the averaged GEM concentrations at 12 remote sites were in the range of $1.60-5.07 \mathrm{ng} \mathrm{m} \mathrm{m}^{-3}$ (mean $=2.86 \pm 0.95 \mathrm{ng} \mathrm{m}^{-3}$ ), generally elevated compared to those observed in North America, Europe, South Africa and South America. Therefore, we may attribute the elevated concentrations in foliage, litter or litterfall to the elevated TGM concentrations in atmosphere in China. Species-specific difference in foliar mercury have been observed in many areas (Hall and St. Louis, 2004; Siwik et al., 2009; Stamenkovic and Gustin, 2009; Niu et al., 2011). In this study, the evergreen broad-leave trees of S. superba Gardn. et and Dicranopteris dichotoma showed higher mercury concentrations compared to the $P$. massoniana conifers, in agreement with similar studies in other areas (Obrist et al., 2009; Grigal, 2003). A likely reason for such difference includes greater leaf area or number of stomas of broad-leaved as suggested by Laacouri et al. (2013). Additionally, the other reason may be that higher TGM concentrations were observed under the canopies of Masson pine $\left(3.8 \pm 1.32 \mathrm{ng} \mathrm{m}^{-3}\right.$, Zhou et al., in preparation) where the broadleave plants (understory) lived and lead to higher mercury concentrations in foliage. The canopies can greatly influence mercury concentrations were also showed in other forests (Barghigiani et al., 1991; Siwik et al., 2009).

Bole wood showed the lowest mercury concentrations (8-15 $\mathrm{ng} \mathrm{g}^{-1}$ ) in plant components. Bole wood concentrations measured at our site were higher than that reported in the north-central part of the USA (0.6-12 $\mathrm{ng} \mathrm{g}^{-1}$ ) (Grigal, 2003), in North America (1.86-2.9 $\mathrm{ng} \mathrm{g}^{-1}$ ) (Engle et al. (2006) and Friedli et al., 2007) and much higher than that in Sierra Nevada (0-0.23 $\mathrm{ng} \mathrm{g}^{-1}$ ) (Obrist et al., 2009). Of other above-ground biomass tissues, bark also exhibited much higher mercury concentration than that in previous studies (Engle et al., 2006; Friedli et al., 2007; Grigal, 2003). Interestingly, mercury in barks obviously increased from fresh to old ones (Supplementary 
Table 1

Mercury concentrations ( $\mathrm{ng} \mathrm{g}^{-1}$ ) in plant components in TFP.

\begin{tabular}{|c|c|c|c|c|c|}
\hline Substrate & Root & Stem/Bolewood & Branch/Twig & Needle/Leaf & Bark \\
\hline Pinus massoniana Lamb & $71 \pm 16$ & $8 \pm 3$ & $20 \pm 5$ & $99 \pm 21$ & $27 \pm 9$ \\
\hline Schima superba Gardn. et Champ. & $25 \pm 5$ & $10 \pm 3$ & $12 \pm 4$ & $148 \pm 249$ & $22 \pm 5$ \\
\hline Ilex chinensis Sims & $55 \pm 13$ & $17 \pm 6$ & $23 \pm 7$ & $210 \pm 46$ & $34 \pm 6$ \\
\hline Dicranopteris dichotoma Bernh. & $49 \pm 9$ & $28 \pm 7$ & & $74 \pm 12$ & \\
\hline Woodwardia japonica Sm. & $36 \pm 10$ & $17 \pm 5$ & & $145 \pm 36$ & \\
\hline Moss & & & $145 \pm 23$ & & \\
\hline Litter & & & $115 \pm 11$ & & \\
\hline
\end{tabular}

information; Fig. SI-1), suggesting that bark can accumulate mercury with times like leaves (Laacouri et al., 2013). Additionally, Hojdová et al. (2011) suggested that tree rings may be an appropriate record of mercury deposition in an area affected by atmospheric mercury pollution. Therefore, the trend of mercury decreases and then increases from the external to the central rings (Fig. SI-1) may reflect the similar mercury deposition trend in the study area, but the specific recorded time should be need more detailed researches.

\subsubsection{Mercury pools in biomass}

In the TFP, the overstory is comprised of Masson pine with mean DHB $20.1 \mathrm{~cm}$. Total biomass and above-ground biomass (excluding root) were 22.7 and $20.1 \mathrm{~kg} \mathrm{~m}^{-2}$, respectively (Fig. 3). Total standing biomass was $19.8 \mathrm{~kg} \mathrm{~m}^{-2}$, of which the overstory and understory layer comprised $98.0 \%$ and $2.0 \%$. Canopy biomass was from $13 \%$ of total above-ground biomass in Masson pine and the proportion of stem to total above-ground biomass was $\sim 78 \%$ and the remained $\sim 9 \%$ was in root (Fig. 3).

Total vegetation mercury pools were calculated separately for overstory, shrub, herb and litter. The mercury stocks in the overstory (Mason pine) and litter layer were $0.41 \pm 0.052 \mathrm{mg} \mathrm{m}^{-2}$ and $0.22 \pm 0.013 \mathrm{mg} \mathrm{m}^{-2}$, respectively, which is much higher than that shrub $\left(0.0088 \pm 0.00074 \mathrm{mg} \mathrm{m}^{-2}\right)$ and herb $\left(0.0033 \pm 0.00010 \mathrm{mg} \mathrm{m}^{-2}\right.$ ) (Fig. 3). The largest mercury pool located in overstory accounted for $63.6 \%$ because of the largest biomass ration of $94.4 \%$. Mercury in biomass, the sum of mercury contained in foliage, bark, branch bole wood, and litter layer (Oi, Oe and $\mathrm{Oa}$ ), was $0.50 \mathrm{mg} \mathrm{m}^{-2}$ (Table 2). In the subtropical forest, litter decomposition rates are high and little litter and organic matter accumulates on the forest floor due to warm and wet summers (Zhu et al., 2013), resulting in the thinness of litter and organic matter horizons. So litter layer presents a small fraction of aboveground biomass allocation (4.1\%). However, it accounts for the

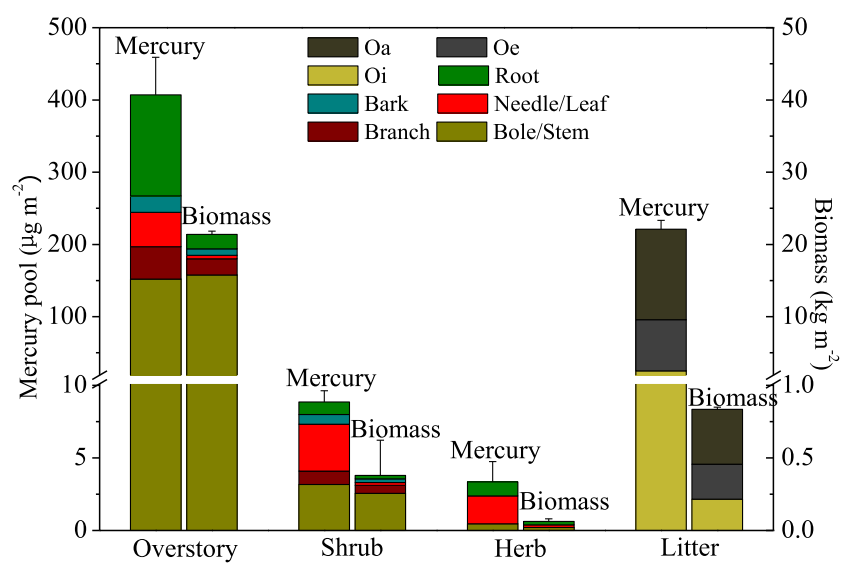

Fig. 3. Mercury pools in biomass and corresponding biomass in TFP (error bars represent standard error calculated for individual 3 replicate plots).
Table 2

Distribution of mercury pool $\left(\mu \mathrm{g} \mathrm{m}^{-2}\right)$ and percentage in biomass tissues in TFP.

\begin{tabular}{lrllrrl}
\hline Substrate & Bole & Branch & Foliage & Bark & Litter & Total \\
\hline Pool & 155.8 & 45.6 & 52.8 & 23.5 & 221.1 & 498.8 \\
Percentage (\%) & 31.2 & 9.1 & 10.6 & 4.7 & 44.3 & 100.0 \\
\hline
\end{tabular}

relatively large amounts of mercury pools (44.3\%), which likely originate from sorbed deposition of atmospheric origin (Zhou et al., 2013). Furthermore, higher mercury pools in the litter layer resulted partly from natural processes of litterfall decomposition and transformation, in which organic matter binding mercury compounds are usually stabilized via complexing, humification and adsorption to affinity of mercury binding groups like thiol (Schlüter, 2000; Gunda and Scanlon, 2013; Zhou et al., 2015b). Although much higher mercury pool in the litter horizon $\left(0.22 \pm 0.013 \mathrm{mg} \mathrm{m}^{-2}\right)$ compared to that reported in America (range from $0.027 \pm 0.0010$ to $0.029 \pm 0.00062 \mathrm{mg} \mathrm{m}^{-2}$, Obrist et al., 2009), it represented much smaller proportion of total mercury storage in TFP (50-75\%) than that in America.

The second largest pools are located in the bole wood which accounted for more than $31.2 \%$ of the total above-ground mercury pool in the TFP. However, the proportions were negligible in California and Nevada, USA (Obrist et al., 2009) and no more than $28.6 \%$ in Saskatchewan, Canada (Friedli et al., 2007). This may be related to elevated TGM concentrations resulted in elevated foliage and soil mercury concentrations in TFP, from which mercury translocated to the bole wood (Barghigiani et al., 1991; Zhou et al., 2015b). About $10.6 \%$ of the above-ground mercury resided in foliage and about $9.1 \%$ in branch, although high in mercury content, contributed little to the stock because of their low mass fractions. The distribution among plant parts has important consequences for mercury emissions: branch, foliage, bark and litter are extensively consumed by fire and release the contained mercury, which combined contain most of the mercury in above ground biomass.

\subsection{Mercury concentrations and pools in soils}

\subsubsection{Mercury concentrations in soils}

Mercury concentrations in soils range between 58 and $332 \mathrm{ng} \mathrm{g}^{-1}$ (Fig. 4) and mineral layers are hence substantially lower than in the overlying litter horizons. Deeper soil layers showed lower mercury concentrations as compared to upper soil horizons which is also evident by our previous study in this area (Zhou et al., 2016), and mercury concentrations drop strongly from A to B horizon. Declining mercury concentrations with soil depth are commonly observed: Zhou et al. (2013) reported declining mercury concentrations from top horizons to deep horizons in a broad-leaf primary forest in Southwestern China; soil concentrations decreased sharply with depth in mineral horizons in Jeffrey pines forest in USA (Obrist et al., 2009); and Liu et al. (2003) reported decreasing mercury concentrations in the peat blog of Xiaoxing'an Mountain, northeastern China with highest mercury 


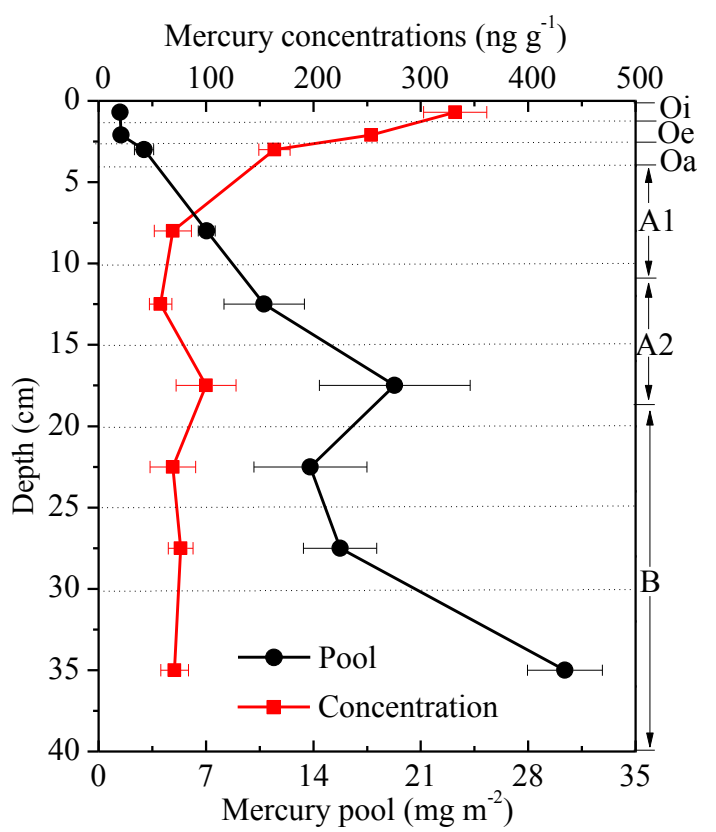

Fig. 4. Mercury concentrations and pools in the soil profile with various thickness in TFP.

concentrations in the top horizons. Mercury concentrations in organic soils in the study forest were higher to the data reported from other forest sites in China (Lin et al., 2012) and North America (St. Louis et al., 2001; Biswas et al., 2008). This is in a good

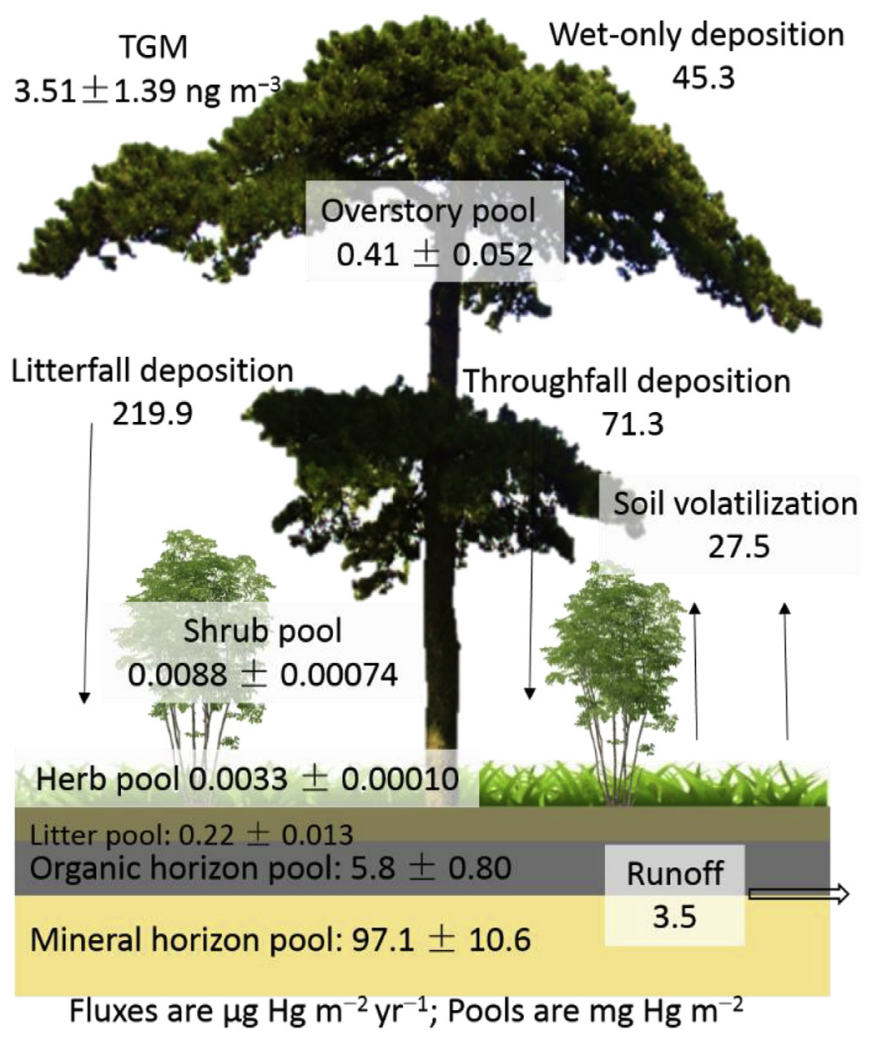

Fig. 5. Total mercury pools in vegetation, organic and mineral horizons at the TFP Masson pine forest. Mercury deposition and runoff fluxes were from Wang et al. (2009); soil volatilization was from our unpublished data (Zhou et al., in preparation). agreement with the elevated loading of mercury in TFP.

\subsubsection{Mercury pool in soils}

The total ecosystem mercury pool, calculated by the above Formula (4), was $103.5 \mathrm{mg} \mathrm{m}^{-2}$ in the subtropical forest (Fig. 5). Fig. 4 also showed mercury pools for individual soil layers with total mercury pool of $102.9 \pm 9.8 \mathrm{mg} \mathrm{m}^{-2}$, which account for $99.4 \%$ of the total ecosystem mercury pools. The mercury pools in the organic (5.8 $\mathrm{mg} \mathrm{m}^{-2}$ ) and mineral topsoil $\left(7.0 \mathrm{mg} \mathrm{m}^{-2}\right)$ in this study were within the range $3.5-24$ and $2.0-12 \mathrm{mg} \mathrm{m}^{-2}$ studied by our previous study on the regional mercury pool distribution in this area. The mercury pools in soil and ecosystem were obviously higher than previous measurement in North America (Friedli et al., 2007; Obrist et al., 2009; Richardson et al., 2013), but lower compared to that in a primary subtropical forest in southwestern China (Zhou et al., 2013). This is in a good agreement with the elevated loading of mercury in subtropical forest areas (Wang et al., 2009; Zhou et al., 2013). Similarly, soils represent the dominant ecosystem mercury pools were the same as other research worldwide: two subtropical forest stands in USA showed over $90 \%$ of the total ecosystem mercury pools to reside in the soils (Engle et al., 2006; Obrist et al., 2009); Friedli et al. (2007) reported from 93 to $97 \%$ of ecosystem mercury resided in organic soils in two subtropical forest stands in Canada.

\subsection{The mercury risk to insects and potential release from wildfires}

\subsubsection{Mercury in insect}

Insects are the important components of ecosystems and could be used to monitor heavy metal pollution for their widely exist in environments (Hsu et al., 2006). In this study, mercury concentrations in three species of cicada, longicorn and Dung beetle were shown in Fig. 6. Mercury concentration in Dung beetle was the highest with the mean of $1983 \pm 446 \mathrm{ng} \mathrm{g}^{-1}$, which was higher in the female than that in male, but with no significant difference $(P>0.05)$. The lowest mercury accumulation was longicorn $\left(7 \pm 5 \mathrm{ng} \mathrm{g}^{-1}\right)$. For cicada, the average mercury concentration was $49 \pm 38 \mathrm{ng} \mathrm{g}^{-1}$, which were higher in C. ochracea and P. kaempferi and lowest in 0 . maculaticollis. Many studies have investigated the insect mercury concentrations in aquatic ecosystem (e.g. Kwon et al., 2015; Rolfhus et al., 2015), there was few research on mercury accumulation in terrestrial insect. Several researches have well

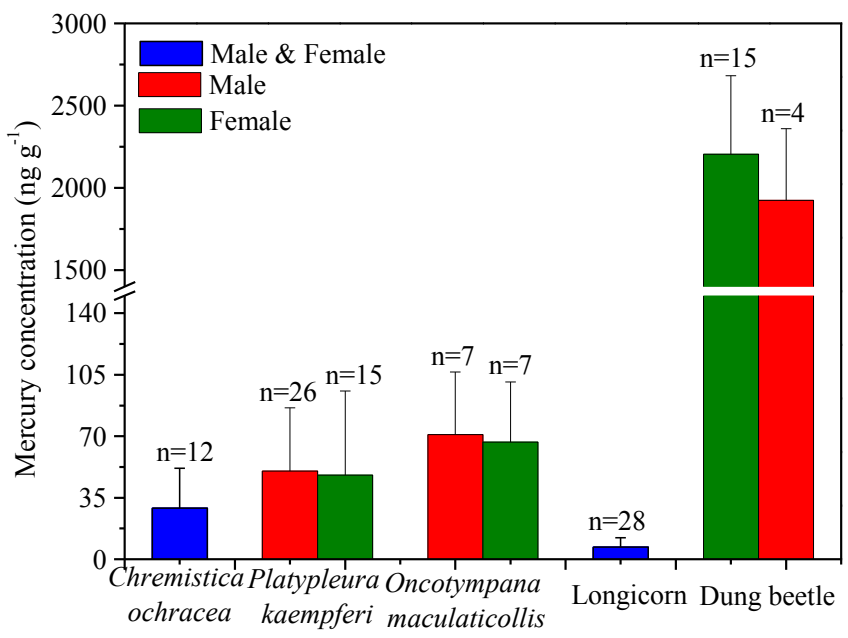

Fig. 6. Mercury concentrations in cicada (Chremistica ochracea, Platypleura kaempferi, Oncotympana maculaticollis), longicorn (Anoplophora chinensis) and dung beetle (Geotrupidae) in TFP. 
studied more than ten insects which were collected from a contaminated grassland in Huludao City, north China (Zhang et al., 2010, 2012; Zheng et al., 2010), and they found that mercury concentrations in all insects exceeded $100 \mathrm{ng} \mathrm{g}^{-1}$ and differed from feeding habits, which is consistent with our observations. Rimmer et al. (2010) investigated mercury concentrations in a terrestrial food web in high elevation forests in Vermont. Interestingly, mercury in tree leaf litter and foliar was similar to our study area. However, the mercury concentrations in the invertebrates were in the range from 1000 to $2000 \mathrm{ng} \mathrm{g}^{-1}$, which were much higher than the mercury concentrations in longicorn and cicada, but comparable with that in Dung beetles. Cristol et al. (2008) studied orthopterans, lepidopterans and spiders in Virginia upland habitats and showed that mean mercury concentrations was dramatically higher ( $>310 \mathrm{ng} \mathrm{g}^{-1}$ ) at contaminated sites. And they also showed relative lower at mercury concentrations reference sites, which were similar to the concentrations we obtained in TFP. Although published data are scant for terrestrial invertebrates, mercury generally increases at successive trophic levels within invertebrate food webs (Rimmer et al., 2010). Heckel and Keener (2007) and Zheng et al. (2010) reported that mercury in female cicada were usually higher than that in males owing to the large body mass of male cicada and diluted mercury concentrations. However, similar mercury concentrations between the sexes were found in our study, which may be referable to no different body mass between male and female ( $\mathrm{p}>0.05)$.

Mercury concentrations in dung beetle was 40 and 283 times higher than that in cicada and longicorn (herbivorous arthropods). We may attributed the different mercury content in insects to special living habits and food intake. Dung beetles were permanently residing in soils and feeding on excrement of other animals and regarded as detritivorous arthropods, where much higher mercury was contained (Costa et al., 2013). Previous researches reported that heavy metals in terrestrial invertebrates were correlated to soil metal concentrations (Heikens et al., 2001) as well as their special ingestion of food (Zheng et al., 2010). Furthermore, adult dung beetle can live 3-5 years resulted in long-term mercury bioaccumulation. Mercury concentrations in cicada was higher than that in longicorn due to special living habits of cicada. Cicada larvae can live underground for about $4-5$ years before their last molting and suck fluid from plant roots for survival, which contained relative higher mercury concentrations than that in bark and wood (Zheng et al., 2010). Therefore, mercury concentrations of the insect decreased in the order of which lived in soils $>$ in soils then on plant $>$ on plant. Moreover, previous study in montane forest food web reflected the transfer of mercury from lower to higher trophic levels with a resulting increase in mercury burden, and the general progression was food web base $<$ herbivorous arthropods $<$ detritivorous arthropods $<$ predatory arthropods < insectivorous vertebrates < carnivorous vertebrates (Rimmer et al., 2010). Although we have not studied such diverse food web in this study, we can predict that mercury will be seriously bioaccumulated on the top of the food chain. Hence, further fully detailed studies are urgently needed to study the mercury bioaccumulation of food web in subtropical forest of China.

\subsubsection{Estimation of potential mercury release from wildfires}

Mercury stock in above-ground mass is very small but very important in the Masson pine forest because it is susceptible to extensive combustion and mercury release during a fire. The accelerated global warming and frequent drought in southwestern China would increase severity, frequency and burn area of potential fires and causing large pulses of mercury to the global atmospheric pool and further stress to the environment (Friedli et al., 2007). Research on soil and biomass mercury emissions during a wildfire in an Amazonian rain forest showed that mercury release rate from different plant components and soil layers differed greatly due to combustion completeness which is defined as the ratio of biomass consumed by fire to total available biomass category (MelendezPerez et al., 2014). In this study, we referenced the combustion completeness suggested by Melendez-Perez et al. (2014) and assumed that all herbs was burnt and mercury was completely emitted to the atmosphere from the complete combustion of biomass. Mercury emission from each type of biomass and soils were shown in Table 3. Harden et al. (2004) applied paired unburned-burned sampling site and considering fire severity method, and estimated mercury release of $0.2 \pm 0.2 \mathrm{mg} \mathrm{m}^{-2}$ for a prescribed burn of a boreal black spruce forest in Alaska. Engle et al. (2006) used total soil mercury to estimate that a desert sagebrush fire, a prescribed conifer fire and a conifer wildfire released mercury ranged from 0.036 to $0.51 \mathrm{mg} \mathrm{m}^{-2}$. Melendez-Perez et al. (2014) calculated mercury emission was $0.41 \pm 0.14 \mathrm{mg} \mathrm{m}^{-2}$ during a prescribed fire in Brazil rain forest using the difference in mercury burden in vegetation and soil before and after burning. The results from our study area generally higher than previous estimates because of higher mercury biomass concentration and pool in our study area. However, Biswas et al. (2007) used a similar technique as Engle et al. (2006), and estimated that a conifer forest wildfire released $0.74-2.53 \mathrm{mg} \mathrm{m}^{-2}$ and deciduous forest fire released 3.6-12.9 $\mathrm{mg} \mathrm{m}^{-2}$, which was higher than that estimated in TFP Masson pine forest. Firstly, it should be noted that thermal desorption of mercury from biomass and soils is strongly dependent on fire severity, mercury speciation and bonding type (Do Valle et al., 2005). The large variations were resulted from observed fire severity in the forest (Biswas et al., 2007). Additionally, although mercury pool in the conifer and deciduous forest living trees was lower, the forest floor accumulated lots of litter and thick organic horizon, which was a large mercury pool and released from the forest fire was significantly higher, while much thinner organic horizons in our Masson pine forest as we started above.

Currently, estimates of natural emissions of mercury are considered to be more indefinite than those of anthropogenic emissions, whereas the natural emissions are roughly half to twothirds of total global $\mathrm{Hg}^{0}$ emissions (Pirrone et al., 2010; Goodsite et al., 2013). The average global annual mercury emission of biomass burning was estimated to $675 \pm 240 \mathrm{t} \mathrm{yr}^{-1}$ in 1997-2006, which was equivalent to $8 \%$ of all currently known anthropogenic and natural mercury emissions (Friedli et al., 2007), while volatilization of mercury during wildfire was an important pathway for the re-emission of atmospherically deposited mercury (Biswas et al., 2007; Engle et al., 2006; Do Valle et al., 2005). In Chongqing City, anthropogenic mercury emissions were estimated approximately $10.05 \mathrm{t}$ and more than $70 \%$ of this total originated in coal combustion in 2010 (Zhang et al., 2015). We hypothesized mercury emission factor from coal combustion was $0.075 \mathrm{~g} \mathrm{t}^{-1}$ which was estimated and calculated from the study of Wang et al. (2006). Based on our estimation, the potential mercury emissions from the wildfire was $0.82 \mathrm{mg} \mathrm{m}^{-2}$. It means that the mercury mass emitted by a hectare of forest burning equivalents approximately to 109.3 t coal combustion in Chongqing City. Additionally, it is worth to noting that besides releasing mercury to the atmosphere and enhancing the transfer of mercury from soil to aquatic environment, forest fire also prevents the mercury from being scavenged from the atmosphere.

\section{Conclusion}

The Masson pine forest in Chongqing subtropical forest contains large stocks of mercury ( $103.5 \mathrm{mg} \mathrm{m}^{-2}$ ) which pose a serious threat for large mercury pulses to the atmosphere during potential 
Table 3

Mercury pool and emission estimated from above-ground biomass and soil in TFP.

\begin{tabular}{|c|c|c|c|c|c|}
\hline Types of biomass & $\begin{array}{l}\text { Dry biomass } \\
\left(\mathrm{kg} \mathrm{m}^{-2}\right)\end{array}$ & $\begin{array}{l}\text { Mean mercury concentration } \\
\left(\mathrm{ng} \mathrm{g}^{-1}\right)\end{array}$ & $\begin{array}{l}\text { Mercury pool in biomass } \\
\left(\mathrm{mg} \mathrm{m}^{-2}\right)\end{array}$ & Combustion completeness & $\begin{array}{l}\text { Mercury emission } \\
\left(\mathrm{mg} \mathrm{m}^{-2}\right)\end{array}$ \\
\hline Leaves/needles & 0.50 & 91 & 0.046 & 0.85 & 0.039 \\
\hline Barks & 0.90 & 26 & 0.024 & $0.85^{\mathrm{a}}$ & 0.020 \\
\hline Litter & 0.22 & 263 & 0.025 & 0.85 & 0.188 \\
\hline Herb & 0.06 & 112 & 0.007 & 1.00 & 0.007 \\
\hline Branch and Fine wood $<10 \mathrm{~cm}$ & 2.6 & 19 & 0.049 & 0.85 & 0.041 \\
\hline Logs $10-30 \mathrm{~cm}$ & 15.8 & 10 & 0.152 & 0.165 & 25.10 \\
\hline Soil depth $(\mathrm{cm})$ & $\begin{array}{l}\text { Dry mass } \\
\left(\mathrm{kg} \mathrm{m}^{-2}\right)\end{array}$ & $\begin{array}{l}\text { Mean mercury concentration } \\
\left(n g^{-1}\right)\end{array}$ & $\begin{array}{l}\text { Mercury pool in soils } \\
\left(\mathrm{mg} \mathrm{m}^{-2}\right)\end{array}$ & Emission rate ${ }^{\mathrm{b}}$ & $\begin{array}{l}\text { Mercury emission } \\
\left(\mathrm{mg} \mathrm{m}^{-2}\right)\end{array}$ \\
\hline Oe & 0.24 & 296 & 0.071 & 0.857 & 0.061 \\
\hline $\mathrm{Oa}$ & 0.38 & 329 & 0.125 & 0.857 & 0.107 \\
\hline $0-1.5$ & 4.20 & 332 & 1.396 & 0.13 & 0.181 \\
\hline $1.5-3$ & 5.83 & 253 & 1.474 & 0.035 & 0.052 \\
\hline $3-4.5$ & 18.13 & 163 & 2.965 & 0.033 & 0.098 \\
\hline Total & & & 6.264 & & 0.819 \\
\hline
\end{tabular}

a The combustion completeness of bark was assumed the same as leaves.

b Emission rate was estimated as the ratio of soil mercury concentration loss by fire to mercury concentration before burn in the literature (Melendez-Perez et al., 2014).

wildfires. About $99.4 \%$ of the mercury resides in the top soil layer to the depth of $40 \mathrm{~cm}$. Elevated TGM level $\left(3.51 \pm 1.39 \mathrm{ng} \mathrm{m}^{-2}\right)$ in ambient air may accelerate foliar uptake and deposition of mercury, which may partly explain the elevated pools observed in TFP. The amount of mercury in biomass is small $\left(0.50 \mathrm{mg} \mathrm{m}^{-2}\right)$, but very important due to it susceptible combustion and mercury release in canopy fires depending on fire severity, notwithstanding together with a fraction of the much larger soil stocks. For our research catchment, the mercury concentrations in live vegetation and atmosphere reflected an atmospheric mercury background with large point sources of industrial activity. The consequences of elevated mercury input were ecological stress to humans and animals, and additionally large fluxes of TGM to the global atmospheric pool during forest fires. Especially for the insects living in the forest soils, mercury concentrations measured in dung beetle were 40 and 283 times higher than that in cicada and longicorn, which can be used to monitor mercury pollution in forest ecosystem.

\section{Acknowledgments}

This research was funded by the National Basic Research Program of China (No. 2013CB430002), "Strategic Priority Research Program" of the Chinese Academy of Sciences (Grant No. XDB14020205) and Natural Science Foundation of China (No. 41373124 and 41371461 ).

\section{Appendix A. Supplementary data}

Supplementary data related to this article can be found at http:// dx.doi.org/10.1016/j.envpol.2016.01.003.

\section{References}

Ariya, P.A., Khalizov, A., Gidas, A., 2002. Reaction of gaseous mercury with atomic and molecular halogens: kinetics, product studies, and atmospheric implications. J. Phys. Chem. A 106, 7310-7320.

Barghigiani, C., Ristori, T., Bauleo, R., 1991. Pinus as an atmospheric Hg biomonitor. Environ. Technol. 12, 1175-1181.

Biswas, A., Blum, J.D., Klaue, B., Keeler, G.J., 2007. Release of mercury from Rocky Mountain forest fires. Glob. Biogeochem. Cycles 21, GB1002. http://dx.doi.org/ 10.1029/2006GB002696.

Biswas, A., Blum, J.D., Keeler, G.J., 2008. Mercury storage in surface soil in a centra Washington forest and estimated release during the 2001 Rex Creek fire. Sci. Total Environ. 404, 129-138.

Blackwell, B.D., Driscoll, C.T., 2015. Using foliar and forest floor mercury concentrations to assess spatial patterns of mercury deposition. Environ. Pollut. 157,
$592-600$.

Chen, C., Wang, H.H., Zhang, W., Hu, D., Chen, L., Wang, X.J., 2013. High-resolution inventory of mercury emissions from biomass burning in China for 2000-2010 and a projection for 2020. J. Geophys. Res. Atmos, 118 (21), 12248-12256.

Choi, H.D., Holsen, T.M., 2009. Gaseous mercury fluxes from the forest floor of the Adirondacks. Environ. Pollut. 157, 592-600.

Clarkson, T.W., 1998. Human toxicology of mercury. J. Trace Elem. Exp. Med. 11, 303-317.

Costa, R.A., Eeva, T., Eira, C., Vaqueiro, J., Vingada, J.V., 2013. Assessing heavy metal pollution using Great Tits (Parus major): feathers and excrements from nestlings and adults. Environ. Monit. Assess. 185, 5339-5344.

Cristol, D.A., Brasso, R.L., Condon, A.M., Fovargue, R.E., Friedman, S.L., Hallinger, K.K., Monroe, A.P., White, A.E., 2008. The movement of aquatic mercury through terrestrial food webs. Science 320, 335.

Do Valle, C.M., Santana, G.P., Augusti, R., Egreja Filho, F.B., Windmoller, C.C., 2005. Speciation and quantification of mercury in Oxisol, Ultisol, and Spodosol from Amazon (Manaus, Brazil). Chemosphere 58, 779-792.

Engle, M.A., Gustin, M.S., Johnson, D.W., Murphy, J.F., Miller, W.W., Walker, R.F., Wright, J., Markee, M., 2006. Mercury distribution in two Sierran forest and one desert sagebrush steppe ecosystem and the effects of fire. Sci. Total Environ. $367,222-233$.

Feng, X., Qiu, G.L., 2008. Mercury pollution in Guizhou, China-an overview. Sci. Total Environ. 400, 227-237.

Friedli, H.R., Radke, L.F., Payne, N.J., McRae, D.J., Lynham, T.J., Blake, T.W., 2007. Mercury in vegetation and organic soil at an upland boreal forest site in Prince Albert National Park, Saskatchewan, Canada. J. Geophys. Res. 112, G01004. http://dx.doi.org/10.1029/2005JG000061.

Fu, X.W., Feng, X.B., Zhu, W.Z., Wang, S.F., Lu, J.L., 2008. Total gaseous mercury concentrations in ambient air in the eastern slope of Mt. Gongga, South-Eastern fringe of the Tibetan plateau, China. Atmos. Environ. 42, 970-979. http:// dx.doi.org/10.1016/j.atmosenv.2007.10.018.

Fu, X.W., Feng, X.B., Dong, Z.Q. Yin, R.S., Wang, J.X., Yang, Z.R., Zhang, H., 2010. Atmospheric gaseous elemental mercury (GEM) concentrations and wet and dry deposition of mercury at a high-altitude mountain peak in south China. Atmos. Chem. Phys. 10, 2425-2437.

Fu, X.W., Zhang, H., Wang, X., Yu, B., Lin, C.-J., Feng, X.B., 2015. Observations of atmospheric mercury in China: a critical review. Atmos. Chem. Phys. Discuss. 15, $11925-11983$.

Gong, P., Wang, X.P., Xue, Y.G., Xu, B.Q. Yao, T.D., 2014. Mercury distribution in the foliage and soil profiles of the Tibetan forest: processes and implications for regional cycling. Environ. Pollut. 188, 94-101.

Goodsite, M.E., Outridge, P.M., Christensen, J.H., Dastoor, A., Muir, D., Travnikov, O. Wilson, S., 2013. How well do environmental archives of atmospheric mercury deposition in the Arctic reproduce rates and trends depicted by atmospheric models and measurements? Sci. Total Environ. 452, 196-207.

Grigal, D.F., 2003. Mercury sequestration in forests and peatlands: a review. J. Environ. Qual. 32, 393-405.

Grigal, D., Kolka, R., Fleck, J., Nater, E., 2000. Mercury budget of an upland-peatland watershed. Biogeochemistry 50, 95-109.

Gunda, T., Scanlon, T.M., 2013. Topographical influences on the spatial distribution of soil mercury at the catchment scale. Water Air Soil Pollut. 224, 1511,. http:// dx.doi.org/10.1007/s11270-013-1511-7.

Hall, B.D., St. Louis, V.L., 2004. Methylmercury and total mercury in plant litter decomposing in upland forests and flooded landscapes. Environ. Sci. Technol. 38, 5010-5021.

Harden, J.W., Neff, J.C. Sandberg, D.V., Turetsky, M.R., Ottmar, R., Gleixner, G., Fries, T.L., Manies, K.L., 2004. Chemistry of burning the forest floor during the FROSTFIRE experimental burn, interior Alaska, 1999. Glob. Biogeochem. Cycles 
18, 3011-3013. GB3014.

Heckel, P.F., Keener, T.C., 2007. Sex differences noted in mercury bioaccumulation in Magicicada cassini. Chemos 69, 79-81.

Heikens, A., Peijnenburg, W.J.G.M., Hendriks, A.J., 2001. Bioaccumulation of heavy metals in terrestrial invertebrates. Environ. Pollut. 113, 385-393.

Hojdová, M., Navratil, T., Rohovec, J., Zak, K., Vanek, A., Chrastny, V., Bace, R., Svoboda, M., 2011. Changes in mercury deposition in a mining and smelting region as recorded in tree rings. Water Air Soil Pollut. 216, 73-82.

Holmes, R.T., Sawyer, R.H., 1975. Oxygen consumption in relation to ambient temperature in five species of forest-dwelling thrushes (Hylocichla and Catharus). Comp. Biochem. Physiol. Part A Physiol. 50, 527-531.

Hsu, M.J., Selvaraj, K., Agoramoorthy, G., 2006. Taiwan's industrial heavy metal pollution threatens terrestrial biota. Environ. Pollut. 143, 327-334.

Johnson, D.W., 1995. Role of carbon in the cycling of other nutrients in forested ecosystems. In: Mc Fee, W.W., Kelly, J.M. (Eds.), Carbon Forms and Functions in Forest Soils. SSSA, Madison, WI, pp. 299-328.

Kwon, S.Y., Blum, J.D., Nadelhoffer, K.J., Dvonch, J.T., Tsui, T.K., 2015. Isotopic study of mercury sources and transfer between a freshwater lake and adjacent forest food web. Sci. Total Environ. 532, 220-229.

Laacouri, A., Nater, E.A., Kolka, R.K., 2013. Distribution and uptake dynamics of mercury in leaves of common deciduous tree species in Minnesota, U.S.A. Environ. Sci. Technol. 47, 10462-10470.

Li, X., Wang, Y., Zhu, J., 2008. Study on the rainfall redistribution of Phyllostachys edulis at different Time-scale in Chongqing Jinyun Mountain. Res. Soil Water Conserv. 15 (6), 101-104 (in Chinese with English abstract).

Li, P., Feng, X.B., Shang, L.H., Qiu, G.L., Meng, B., Liang, P., Zhang, H., 2009. Mercury pollution from artisanal mercury mining in Tongren, Guizhou, China. Atmos. Environ. 23, 2055-2064.

Lin, Y., Vogt, R., Larssen, T., 2012. Environmental mercury in China: a review. Environ. Toxicol. Chem. 31, 2431-2444.

Liu, R.H., Wang, Q.C., Lu, X.G., Fang, F.M., Wang, Y., 2003. Distribution and speciation of mercury in the peat bog of Xiaoxing'an Mountain, northeastern China. Environ. Pollut. 124, 39-46.

St. Louis, V.L., Rudd, W.M., Kelly, C.A., Hall, B.D., Rolfhus, K.R., Scott, K.J., Lindberg, S.E., Dong, W., 2001. Importance of the forest canopy to fluxes of methyl mercury and total mercury to a boreal ecosystem. Environ. Sci. Technol. 35, 3089-3098.

Mazur, M., Mitchell, C.P.J., Eckley, C.S., Eggert, S.L., Kolka, R.K., Sebestyen, S.D., Swain, E.B., 2014. Gaseous mercury fluxes from forest soils in response to forest harvesting intensity: a field manipulation experiment. Sci. Total Environ. 496, $678-687$.

Melendez-Perez, J.J., Fostier, A.H., Santos, J.C., Carvalho, J.A., 2014. Soil and biomass mercury emissions during a prescribed fire in the Amazonian rain forest. Atmos. Environ. 96, 415-422.

Melieres, M.A., Pourchet, M., Charles-Dominique, P., Gaucher, P., 2003. Mercury in canopy leaves of French Guiana in remote areas. Sci. Total Environ. 311, $261-267$.

Niu, Z., Zhang, X., Wang, Z., Ci, Z., 2011. Mercury in leaf litter in typical suburban and urban broadleaf forests in China. J. Environ. Sci. 23 (12), 2042-2048.

Obrist, D., Johnson, D.W., Lindberg, S.E., 2009. Mercury concentrations and pools in four Sierra Nevada forest sites, and relationships to organic carbon and nitrogen. Biogeosciences 6, 765-777.

Pirrone, N., Cinnirella, S., Feng, X., Finkelman, R.B., Friedli, H.R., Leaner, J., Mason, R., Mukherjee, A.B., Stracher, G.B., Streets, D.G., Telmer, K., 2010. Global mercury emissions to the atmosphere from anthropogenic and natural sources. Atmos. Chem. Phys. 10 (13), 5951-5964

Poissant, L., Hoenninger, G., Pilote, M., Leser, H., Sebastian, O., Platt, U., 2002. Atmospheric mercury speciation \&ozone depletion events observed at low latitude on the shore of the Hudson Bay in Northern Quebec (kuujjuarapik: 55n) along to bro (doas) measurements. EGS Gen. Assem. Conf. Abstr. 27, 2898.

Raich, J.W., Schlesinger, W.H., 1992. The global carbon dioxide flux in soil respiration and its relationship to vegetation and climate. Tellus B 44, 81-99.

Raisanen, J., 1997. Objective comparison of patterns of $\mathrm{CO}_{2}$ induced climate change in coupled GCM experiments. Clim. Dyn. 13, 197,. http://dx.doi.org/10.1007/ 003820050160.

Rasmussen, P.E., 1995. Temporal variation of mercury in vegetation. Water Air Soil Pollut. 80, 1039-1042.

Rasmussen, P., Mierle, G., Nriagu, J., 1991. The analysis of vegetation for total mercury. Water Air Soil Pollut. 56, 379-390.

Richardson, J.B., Friedland, A.J., Engerbretson, T.R., Kaste, J.M., Jackson, B.P., 2013. Spatial and vertical distribution of mercury in upland forest soils across the northeastern United States. Environ. Pollut. 182 (6), 127-134.

Rimmer, C.C., Miller, E.K., Mcfarland, K.P., Faccio, S.D., Strong, A.B., Taylor, R.J., Faccio, S.D., 2010. Mercury bioaccumulation in a terrestrial food web of a montane forest. Ecotoxicology 19, 697-709. http://dx.doi.org/10.1007/s10646009-0443-X.

Rolfhus, K.R., Wiener, J.G., Haro, R.J., Sandheinrich, M.B., Bailey, S.W., Seitz, B.R., 2015. Mercury in streams at grand portage national monument (Minnesota USA): assessment of ecosystem sensitivity and ecological risk. Sci. Total Environ.
$514,192-201$.

Schlüter, K., 2000. Review: evaporation of mercury from soils. an integration and synthesis of current knowledge. Environ. Geol. 39, 249-271.

Siwik, E.I.H., Campbell, L.M., Mierle, G., 2009. Fine-scale mercury trends in temperate deciduous tree leaves from Ontario, Canada. Sci. Total Environ. 407, 6275-6279.

Stamenkovic, J., Gustin, M.S., 2009. Nonstomatal and stomatal uptake of atmospheric mercury. Environ. Sci. Technol. 43, 1367-1372.

Stankwitz, C. Kaste, J.M., Friedland, A.J., 2012. Threshold increases in soil lead and mercury from tropospheric deposition across an elevational gradient. Environ. Sci. Technol. 46, 8061-8068.

Surhone, L.M., Tennoe, M.T., Henssonow, S.F., (Eds.), World Reference Base for Soil Resources.

Townsend, J.M., Driscoll, C.T., Rimmer, C.C., McFarland, K.P., 2014. Avian, salamander, and forest floor mercury concentrations increase with elevation in a terrestria ecosystem. Environ. Toxicol. Chem. 33, 208-215.

US EPA (United States Environmental Protection Agency), 1997. Mercury Study Report to the Congress, Volume V: Health Effects of Mercury and Mercury Compounds. United States Environmental Protection Agency, Washington.

US EPA (United States Environmental Protection Agency), 1999. Method 1631. Revision B: Mercury in Water by Oxidation, Purge and Trap, and Cold Vapor Atomic Fluorescence Spectrometry, pp. 1-33.

Wang, D., He, L., Wei, S., Feng, X., 2006. Estimation of mercury emission from different sources to atmosphere in Chongqing, China. Sci. Total Environ. 366, 722-728. http://dx.doi.org/10.1016/j.scitotenv.2005.09.054.

Wang, Z.W., Zhang, X.S., Xiao, J.S., Ci, Z.J., Yu, P.Z., 2009. Mercury fluxes and pools in three subtropical forested catchments, southwest China. Environ. Pollut. 157, 801-808.

Wyman, K.E., Rodenhouse, N.L., Bank, M.S., 2011. Mercury bioaccumulation, speciation, and influence on web structure in orb-weaving spiders from a forested watershed. Environ. Toxicol. Chem. 30, 1873-1878.

Xu, P., Hao, Q., Ji, D., Zhang, J., Liu, Z., Hu, B., Wang, Y., Jiang, C., 2015. Characteristics of atmospheric pollutants PM2.5, NOx, SO2 and 03 in Beibei, Chongqing district. Acta Sci. Circumst. (In Chinese with English abstract) http://www.cnki.net/ kcms/detail/11.1843.X.20151104.1656.004.html.

Yang, Y.K., Chen, H., Wang, D.Y., 2009. Spatial and temporal distribution of gaseous elemental mercury in Chongqing, China. Environ. Monit. Assess. 156, 479-489. http://dx.doi.org/10.1007/s10661-008-0499-8.

Ye, X., Hu, D., Wang, H., Chen, L., Xie, H., Zhang, W., Deng, C., Wang, X., 2015. Atmospheric mercury emissions from China's primary nonferrous metal $\mathrm{Zn}, \mathrm{Pb}$ and $\mathrm{Cu}$ ) smelting during 1949-2010. Atmos. Environ. 103, 331-338.

Zhang, L.X., Zhou, T.J., 2015. Drought over East Asia: a review. J. Clim. 28, 3375-3399.

Zhang, Z., Wang, Y., Yuan, Y., Li, Z., Cao, L., Zhang, G., Yu, P., Wang, Y., 2006. Study on the biomass structure and distribution of natural secondary forest of Pinus massoniana. J. Agric. Univ. Hebei 37-43 (In Chinese with English abstract).

Zhang, Z.S., Wang, Q.C., Zheng, D.M., Zheng, N., Lu, X.G., 2010. Mercury distribution and bioaccumulation up the soil-plant-grasshopper-spider food chain in Huludao City, China. J. Environ. Sci. 22, 1179-1183.

Zhang, Z., Song, X., Wang, Q., Lu, X., 2012. Mercury bioaccumulation and prediction in terrestrial insects from soil in Huludao City, Northeast China. Bull. Environ. Contam. Toxicol. 89 (1), 107-112.

Zhang, L., Wang, S., Wang, L., Wu, Y., Duan, L., Wu, Q., Wang, F., Yang, M., Yang, H., Hao, J., Liu, X., 2015. Updated emission inventories for speciated atmospheric mercury from anthropogenic sources in China. Environ. Sci. Technol. 49, 3185-3194.

Zheng, D., Zhang, Z., Wang, Q., 2010. Total and methyl mercury contents and distribution characteristics in Cicada, Cryptotympana atrata (Fabricius). Bull. Environ. Contam. Toxicol. 84, 749-753.

Zhou, J., Feng, X., Liu, H., Zhang, H., Fu, X., Bao, Z., Wang, X., Zhang, Y., 2013. Examination of total mercury inputs by precipitation and litterfall in a remote upland forest of Southwestern China. Atmos. Environ. 81, 364-372.

Zhou, J., Liu, H., Du, B., Shang, L., Yang, J., Wang, Y., 2015a. Influence of soil mercury concentration and fraction on bioaccumulation process of inorganic mercury and methylmercury in rice (Oryza sativa L.). Environ. Sci. Pollut. Res. 22, $6144-6154$.

Zhou, J., Wang, Z., Zhang, X., Chen, J., 2015b. Distribution and elevated soil pools of mercury in an acidic subtropical forest of southwestern China. Environ. Pollut. 202, 187-195. Sd.

Zhou, J., Wang, Z., Zhang, X., Sun, T., 2016. Investigation of factors affecting mercury emission from subtropical forest soil: a field controlled study in southwestern China. J. Geochem. Explor. http://dx.doi.org/10.1016/j.gexplo.2015.10.007.

Zhou, J., Wang, Z., Tang, X., Sun, T., Zhang, X. Air-surface mercury fluxes and gaseous mercury in vertical soil profiles in a subtropical forest of Southwestern China. In preparation.

Zhu, J., Mulder, J., Solheimslid, S.O., Dörsch, P., 2013. Functional traits of denitrification in a subtropical forest catchment in China with high atmogenic $\mathrm{N}$ deposition. Soil Biol. Biochem. 57 (3), 577-586. 